\title{
Violence, Responsibility, Friendship and Basic Psychological Needs: Effects of a Sport Education and Teaching for Personal and Social Responsibility Program
}

\author{
José I. Menéndez-Santurio and Javier Fernández-Río \\ University of Oviedo
}

\begin{abstract}
The goal of the present study was to empirically assess the effects of an intervention based on a hybrid pedagogical model (Sport Education+Teaching for Personal and Social Responsibility) on adolescents' attitudes towards violence, responsibility, friendship goals and basic psychological needs, compared with a traditional teaching approach. 143 secondary education students agreed to participate, 1417 years, 78 experimental and 65 control. A pretest-posttest repeated measures design with a control group was used. Prior and after the program (16 sessions) four assessment instruments were used: Attitudes towards Violence Scale, Friendship Goals Questionnaire, Personal and Social Responsibility Questionnaire and Social Basic Psychological Needs Scale. Posttests MANCOVAs revealed that the intervention program (SE+TPRS) produced a significant improvement in the participants' attitudes towards violence, social responsibility, competence and relatedness. Results show the goodness of using innovative pedagogical approaches.
\end{abstract}

Keywords: pedagogical models, physical education, innovation, educational kickboxing.

\section{Resumen}

El objetivo del presente estudio fue evaluar experimentalmente los efectos de una intervención basada en un modelo pedagógico híbrido (Educación Deportiva+Responsabilidad Personal y Social) sobre las actitudes hacia la violencia, la responsabilidad, las metas de amistad y las necesidades psicológicas básicas de los adolescentes, comparándolos con un planteamiento tradicional de enseñanza. Accedieron a participar 143 estudiantes de secundaria, 14-17 años, 78 experimentales y 65 de control. El estudio utilizó un diseño de medidas repetidas pretest-postest con grupo de control. Antes y después del programa (16 sesiones) se administraron cuatro instrumentos de evaluación: Escala del Nivel de Actitud hacia la Violencia, Cuestionario de Metas de Amistad, Cuestionario de Responsabilidad Personal y Social y Escala de las Necesidades Psicológicas Básicas. Los MANCOVAs postest revelaron que el programa de intervención (MED+MRPS) provocó una mejora significativa de las actitudes hacia la violencia, la responsabilidad social, la competencia y la relación de los participantes. Los resultados muestran la bondad de planteamientos pedagógicos novedosos.

Palabras clave: modelos pedagógicos, educación física, innovación, kickboxing educativo.

Acknowledgements: To the Rosario de Acuña high school (Gijón, Asturias) and to the Emilio Alarcos high school (Gijón, Asturias) for supporting this project.

Correspondence concerning this article should be addressed to José Ignacio Menéndez Santurio, Educational Sciences Department, Faculty of Teacher Training and Education, University of Oviedo. C/ Aniceto Sela s/n, office 219,33005, Oviedo (Spain).E-mail: UO194643@uniovi.es 


\section{Introduction}

Due to current necessities in todays' society, over the last few years the number of research studies on school violence and its relationship with repeated violence conducts such as bullying or cyberbullying has grown rapidly (Boulton, 2013; Carrasco, Alarcón, \& Trianes, 2015; Garaigordobil \& Martínez-Valderrey, 2014). One of the main current educational goals is to build a positive social climate in schools which could help students learn, but also produce improve their global development. However, school violence can hinder these goals (Cava, Buelga, Musitu, \& Murgui, 2010). Violence could be defined as an intentional conduct whose aim is to produce damage or injury (Álvarez-García, Rodríguez, González-Castro, Núñez, \& Álvarez, 2010). There are several types of violence such as physical violence (this could be direct when there is direct contact with the victim or indirect when the damage is on the victim's properties), verbal violence (insults, rumours and nicknames), class disruption (prevent the teacher from conducting the class), social exclusion (discrimination and rejection conducts for academic, racial, social or cultural reasons), and the one that is produced through the new information and communication technologies, also known as cyber bullying (Álvarez-García, Dobarro, Álvarez, Núñez, \& Ro- dríguez, 2014; Garaigordobil \& Martínez-Valderrey, 2014). All of them should be prevented through specifically designed educational programs and interventions.

Motivation is an important element to be able to understand individuals' conduct, and it is being profusely researched. However, social aspects of motivation have been scarcely researched (Méndez-Giménez, Fernández-Río, \& Cecchini, 2014; Wallhead, Garn, \& Vidoni, 2013), despite the call for a wider knowledge on individual's social motivations (King \& McInerney, 2012). Friendship is one of the social goals identified. Elliot, Gable, and Mapes (2006) used the framework approachavoidance to this variable defining friendship-approach goals as those who push individuals to positive relationship outcomes, while friendship-avoidance goals move individuals away from negative outcomes.

Within the Self-determination Theory (Deci \& Ryan, 1985), individual's motivation can also be influenced by three basic psychological needs directly linked to the individual's social context: autonomy, competence and relatedness (Deci \& Ryan, 1985). Autonomy can be defined as the desire of being the responsible of one's behaviour. Competence is the individual's perception of being effective in one's context. Finally, relatedness refers to the feeling of belonging to a social group. The basic 
VIOLENCE, RESPONSIBILITY, FRIENDSHIP AND BASIC PSYCHOLOGICAL NEEDS:

EFFECTS OF A SPORT EDUCATION AND TEACHING FOR PERSONAL

psychological needs have been assessed on their connections with other variables such as social goals (Garn \& Wallhead, 2014), important role, motivational regulations (Méndez-Giménez, FernándezRío, \& Cecchini-Estrada, 2013) and self-concept or intrinsic motivation (Standage, Duda, \& Ntoumanis, 2005), which is related to personal and social responsibility (Escartí, Gutiérrez, \& Pascual, 2011).

Responsibility is the moral duty that one has with oneself and others. The values linked to personal responsibility are effort and autonomy, while the ones linked to social responsibility are the respect for others' feelings and rights, empathy and social sensibility (Hellison, 2011). Responsibility has been assessed in educational context and in physical education (Caballero, 2015; Escartí, Gutiérrez, Pascual, \& Marín, 2010; Gordon, 2010; Turnnidge, Côté, \& Hancock, 2014). The reason behind this particular interest could be that this class creates a particular context where the absence of barriers such as chairs and tables promotes the acquisition of personal competences, and specially, the social ones (McHugh, 1995). Moreover, the physical education class allows youngsters show in a comfortable context their personal and social competences, which are difficult to show in other classes (Hellsion, 2011).

Over the last few years, there has been an evolution in the field of physical education and sport pedagogy from instructional to pedagogical models (Haerens, Kirk, Cardon, \& de Bourdeaudhuij, 2011). The term instructional represents a view of the teachinglearning process focused on the teacher, while the modern vision of this process demands a focus on learning (on the students). The term pedagogical model highlights the interdependence and irreducibility of learning, teaching, content and context (Rovegno, 2006). The pedagogical models of Sport Education (SE; Siedentop, Hastie, \& van der Mars, 2011) and Teaching for Personal and Social Responsibility (TPSR; Hellison, 2011) have been revealed as capable of producing positive changes in significant variables such as the personal and social responsibility (Gordon, 2010), participation (García, Gutiérrez, González, \& Valero, 2012) or motivation (Wallhead et al., 2013) in youngsters of different ages. SE has been widely researched (Hastie, Martínez de Ojeda, \& Calderón, 2011), and the same has happened with TPSR (Gordon \& Doyle, 2015). However, as mentioned by Joyce and Weil (1985) there is no single model that fits every student. Hybridizing pedagogical models can help increase the potentialities of the individual models, truly reaching every type of student (Fernández-Río, 2014) y creating a more effective framework for teachers and students (FernándezRío, 2015). Model hybridization can produce important pedagogi- 
cal benefits, because it looks at the teaching-learning process from different perspectives. To our knowledge, only Hastie and Buchanan (2000) hybridized SE and TPSR models. Results showed that it can increase students' social responsibility, sport competence and personal empowerment.

Based on the aforementioned, the main goal of this study was to experimentally assess the effects of a hybrid SE+TPSR pedagogical model on secondary education students' attitudes towards violence, responsibility, friendship goals and basic psychological needs comparing them with a traditional instructional approach. Four hypotheses were set: (H1) the SE+TPSR intervention will improve students' attitudes towards violence; (H2) the hybrid program will increase students' responsibility levels; (H3) the intervention based on pedagogical models will increase students friendship levels; and (H4) the students in the experimental group will improve their basic psychological needs.

\section{Method}

\section{Participants}

143 students (69 males and 74 females) enrolled in 8 natural groups from grade 10 , age range $14-17$ years $(M=15.44, S D=.80)$, in two different high schools in northern Spain. The control group
(CG) included 65 students (3 natural groups), while the experimental group (EG) included 78 students (5 natural groups). There were 31 males $(47.7 \%)$ and 34 women $(52.3 \%)$ in the EG. On the other hand, there were 38 men $(48.7 \%)$ and 40 women $(51.3 \%)$ in the CG. Non probability sampling for convenience and intact classes were used. None of the students in the EG have had any previous experience on SE or TPSR.

\section{Instruments}

Attitudes towards Violence Scale. This questionnaire, validated by Tejero-González, Balsalobre-Fernández, and IbáñezCano (2011), was used. It includes 10 items which asses two variables: senseless violence (6 items), for example item 6: "It is funny to laugh at the most intelligent classmates", and self-protection violence (4 items), for example item 2: A confident and courageous person $\mathrm{n}$ individual and brave knows how to beat". Moreover, the scale allows to assess global violence merging both subscales. To assess composite reliability (CR) and average variance extracted (AVE) a confirmatory factor analysis was conducted using the maximum likelihood method to estimate the parameters. Results showed a high $\mathrm{FC}=.89$ and an AVE below .50 $(44.6 \%)$. Cronbach's alpha $=.83$ and McDonald's Omega $=.74$ were also calculated. 
VIOLENCE, RESPONSIBILITY, FRIENDSHIP AND BASIC PSYCHOLOGICAL NEEDS:

EFFECTS OF A SPORT EDUCATION AND TEACHING FOR PERSONAL

Friendship Goals in Pysical Education Questionnaire. The Spanish version of the Relationship Goals Questionnaire-Friendship version (Elliot et al., 2006), validated by Mendez-Gimenez et al. (2014), was used. The questions were prefaced by the following sentence: "In my physical education classes I try to...". 8 Items assess friendshipapproach (4 items), for example item 1: deepen in the relations with my friends", and friendship-avoidance (4 items), for example item 5: "avoid situations that could hurt my friends". To assess composite reliability (CR) and average variance extracted (AVE) a confirmatory factor analysis was conducted using the maximum likelihood method to estimate the parameters. Results showed a high $\mathrm{FC}=.90$, an AVE above $.50(53.75 \%)$. Cronbach's alpha was .81 , while McDonald's Omega was .73.

Personal and Social Responsibility in Physical Education Contexts Questionnaire. The Spanish version of the Personal and Social Responsibility Questionnaire (Li, Wright, Rukavina, \& Pickering, 2008), validated by Escartí et al. (2011), was used. At the beginning, it indicates: "It is normal to behave good and bad at times. We want to know how you normally behave in physical education. There are no right or wrong answers. Please, answer honestly to the following questions and circle a number". The scale assesses two dimensions: so- cial responsibility (7 items), for example number 2: "I respect my teacher", and personal responsibility (7 items), for example number 11: "I try to strive even if I don't like the task. To assess composite reliability (CR) and average variance extracted (AVE) a confirmatory factor analysis was conducted using the maximum likelihood method to estimate the parameters. Results showed a high $\mathrm{FC}=.93$, an AVE above .50 (50.78\%). Cronbach's alpha was .83 , while McDonald's Omega was .69.

Basic Psychological Needs in Physical Education Scale. The Spanish version of the Basic Psychological Needs in Physical Education Scale (Vlachopoulos, Katartzi, \& Kontou, 2011), validated by Menendez and Fernandez-Rio (in press), was used. At the beginning of the scale, it says: "Overall, in physical education...". The scale assesses three dimensions: competence (4 items) for example item 4: "I believe that I perform correctly even in the tasks that most classmates consider difficult", relatedness (4 items) for example item 2: "The relations with my classmates are very friendly", and autonomy (4 items) for example 12: "I feel like I have chosen the tasks we perform". To assess composite reliability $(\mathrm{CR})$ and average variance extracted (AVE) a confirmatory factor analysis was conducted using the maximum likelihood method to estimate the parameters. 
Results showed a high $\mathrm{FC}=.95$, an AVE above .50 (62.75\%). Cronbach's alpha was .81 , while McDonald's Omega was .73.

In the first two instruments participants responded in a 1 to 5 likert scale, in the third one from 1 to 6 and in the last one from 1 to 7.

\section{Procedure and design}

First, permission from the Ethical Committee from the university researchers was obtained. Second, the participating schools' principals were contacted to seek their collaboration. Third, a written informed consent was obtained from the participants' parents. At all times, the study complied with the ethical values of research in humans.

The study followed a quasiexperimental design with $\mathrm{CG}$ and pretest-postest repeated measures. The CG experienced a contactless educational kickboxing program taught using a traditional teaching approach (TA). On the other hand, the same content was used with the EG, but a hybrid SE+TPSR pedagogical model was used. Prior to the implementation, the questionnaires later described were administered. Participants were asked to answer as truthfully as possible, informing them that their answers would be kept anonymous and would not affect their grades. At the end of the intervention, the same questionnaires were administered again using the same procedure. The independent variables
(IV) of the study were both intervention programs, while the dependent variables were the violence, friendship, responsibility and basic psychological needs' results.

\section{Intervention program}

To guarantee program fidelity (SE+TPSR), we followed Hastie and Casey (2014, p. 423): "(a) rich description of the curricular elements of the unit; (b) a detailed validation of model implementation; and (c) a detailed description of the program context". Therefore, a 16-session intervention was planned and implemented based on both pedagogical models. Regarding SE, its 6 basic characteristics were included (Siedentop et al., 2011): (1) season: long-term work; (2) affiliation: group cohesion; (3) regular competition: opportunities to test the acquired knowledge; (4) record keeping: to register information; (5) final event: a goal for everyone; and (6) festivity: fun time. Two more elements were also promoted: (1) cooperative learning: positive interdependence, promotive interaction, individual accountability, interpersonal skills and group processing, and (2) roles: conditioning coach, coach, equipment manager, judge, photographer and choreographer. Regarding TPSR, sessions followed the framework developed by Hellison (2011): (1) relational time: the teacher prior, during and after each class interacted with the students 
to build this link; (2) awareness talks: to emphasize the responsibility levels; (3) opportunities for practice: for the students to behave according to the levels; (4) group meetings: to debate and reflect; and (5) self-reflection time: self-evaluation, think about what has happened in class regarding responsibility. When necessary, strategies for specific problems and situations were also used.

Each session lasted 55 minutes and they were conducted by a physi- cal education teacher with more than 10 years of kickboxing experience. This teacher attended a 30-hour training seminar on both pedagogical models to improve his knowledge. It included 12 hours of theory and 16 hours of practice, which included games, tasks and pre-designed sessions to practice, analyze and develop the final version of the learning unit that it was going to be implemented. A pilot study was conducted to test the different tasks designed and develop the fi-

Table 1

Activity Plan of both Educational Kickboxing Interventions

\begin{tabular}{|c|c|c|c|}
\hline Session & $\mathrm{SE}+\mathrm{TPSR}$ & Session & TA \\
\hline 1 & $\begin{array}{l}\text { - Introduction of SE and TPSR: } \\
\text { daily roles, team formation, coun- } \\
\text { try selection, responsibility levels. }\end{array}$ & 1 & $\begin{array}{l}\text { - Learning unit introduction and ba- } \\
\text { sic stance. }\end{array}$ \\
\hline $2-4$ & $\begin{array}{l}\text { - Technical skills: jab and cross } \\
\text { punches, front kick and shifts; } \\
\text { hook punch, round kick and defen- } \\
\text { sive techniques; uppercut punch, } \\
\text { side kick and combinations. }\end{array}$ & $2-3$ & $\begin{array}{l}\text { - Shifts and kickboxing basic } \\
\text { punches techniques: jab, cross, up- } \\
\text { percut and hook. }\end{array}$ \\
\hline 5 & $\begin{array}{l}\text { - Countries' parade and national an- } \\
\text { thems. }\end{array}$ & $4-5$ & $\begin{array}{l}\text { - Kickboxing basic leg techniques: } \\
\text { round, front and side kick. }\end{array}$ \\
\hline $6-8$ & $\begin{array}{l}\text { - Review of skills. } \\
\text { - Competitive phase 1: basic kick- } \\
\text { boxing techniques. }\end{array}$ & 6 & $\begin{array}{l}\text { - Kickboxing basic defensive tech- } \\
\text { niques: feints and dodges. }\end{array}$ \\
\hline $9-14$ & $\begin{array}{l}\text { - Music selection. } \\
\text { - Musical form elaboration. }\end{array}$ & $7-8$ & $\begin{array}{l}\text { - Kickboxing basic techniques per- } \\
\text { fection. }\end{array}$ \\
\hline 15 & $\begin{array}{l}\text { - Rehearsal. } \\
\text { - Competitive phase } 2: \text { musical } \\
\quad \text { forms, final event. }\end{array}$ & $9-15$ & $\begin{array}{l}\text { - Group formation, music selection, } \\
\text { design and presentation of a musi- } \\
\text { cal form. }\end{array}$ \\
\hline 16 & - Awards ceremony: Festivity. & 16 & - Written test. \\
\hline
\end{tabular}


nal version of the intervention program (Menendez \& Fernandez-Rio, 2014). A combination of different strategies: seminars, pre-designed sessions, video analysis and feedback cycles were used to provide an adequate training and s support to the teacher prior and during all the research program (Braithwaite, Spray, \& Warburton, 2011).

The TA intervention followed a traditional instructional framework: teaching and learning of the basic kickboxing skills through repetitive drills, design and presentation of a musical form to the rest of the class and a final written exam. Despite the fact that most TA learning units usually last less than 8 sessions, to match its length to the one of the EG, 16 sessions were developed. The goal was to have the same time of exposure on both interventions. Table 1 outlines the main features of both intervention programs.

To validate the implementation of both approaches, a 10item checklist was developed. It reflected the main features of each of the instructional design used (SE, TPSR, TA). All sessions were videotaped. 8 were randomly selected and sent to 2 independent researchers, experts on all instructional designs, to verify the intervention programs. Observers reached $100 \%$ agreement on models' fidelity.

\section{Data analysis}

All analyses were performed using the statistical software pack- age SPSS 22.0 (IBM, 2013). Regarding missing data, all questionnaires with any item unanswered were eliminated $(n=3)$. First, initial homogeneity between groups was assessed through an analysis of variance (ANOVA) at the pretests. Second, descriptive statistics (means and standard deviations) and multivariate analysis of covariance (MANCOVA) using the variable group as a factor with 2 levels (experimental and control) were conducted to assess the impact of both programs. The posttest results from the different variables assessed were considered the dependent variables, while the same measures, but in the pre-test were used as covariables. Finally, effect size (Cohen's d) was also assessed (small < 0.5; moderate 0.50-0.79; large $\geq 0.80$ ).

\section{Results}

The ANOVA pretests revealed that all variables were homogeneous except for the attitudes towards violence and its sub-scales (senseless violence, self-protection violence and global violence), whose significance levels were above .05 $(p>.05)$. The fact that both groups (EG and CG) belonged to different high schools could be the cause of that difference.

Table 2 shows all results. Regarding social responsibility, the MANCOVA showed significant differences among groups

Revista de Psicodidáctica, 2016, 21(2), 245-260 
Table 2

Pretest and Posttest Means and Standard Deviations in Experimental and Control Groups and Pretest ANOVAS and Posttest MANCOVAS

\begin{tabular}{|c|c|c|c|c|c|c|c|c|c|c|c|c|c|c|}
\hline & \multicolumn{4}{|c|}{ Pretest } & \multicolumn{4}{|c|}{ Posttest } & \multirow{2}{*}{\multicolumn{3}{|c|}{ Anova Pretest }} & \multirow{2}{*}{\multicolumn{3}{|c|}{ Mancova Posttest }} \\
\hline & \multicolumn{2}{|c|}{ Experimental } & \multicolumn{2}{|c|}{ Control } & \multicolumn{2}{|c|}{ Experimental } & \multicolumn{2}{|c|}{ Control } & & & & & & \\
\hline & $M$ & $S D$ & $M$ & $S D$ & $M$ & $S D$ & $M$ & $S D$ & $F$ & $p$ & $d$ & $F$ & $p$ & $d$ \\
\hline Friendship-Approach & 3.58 & .68 & 3.63 & .62 & 3.87 & .67 & 3.64 & .70 & .19 & $>.05$ & 0.07 & 3.58 & .06 & 0.33 \\
\hline Friendship- Avoidance & 3.80 & .69 & 3.68 & .80 & 3.73 & .81 & 3.77 & .91 & .90 & $>.05$ & 0.16 & .99 & .32 & 0.04 \\
\hline Social Responsibility & 4.99 & .56 & 4.89 & .77 & 5.29 & .55 & 4.93 & .77 & .86 & $>.05$ & 0.14 & 10.97 & .001 & 0.53 \\
\hline Personal Responsibility & 4.71 & .81 & 4.75 & .68 & 5.05 & .40 & 4.90 & .41 & .06 & $>.05$ & 0.05 & 2.41 & .12 & 0.37 \\
\hline Competence & 4.07 & 1.33 & 3.85 & 1.56 & 4.78 & 1.28 & 4.04 & 1.52 & .82 & $>.05$ & 0.15 & 13.17 & .000 & 0.52 \\
\hline Autonomy & 4.17 & 1.25 & 3.84 & 1.24 & 4.32 & 1.34 & 3.92 & 1.35 & 2.42 & $>.05$ & 0.26 & 1.19 & .27 & 0.29 \\
\hline Relatedness & 4.37 & 1.22 & 4.60 & 1.53 & 5.47 & 1.04 & 4.81 & 1.37 & .92 & $>.05$ & 0.16 & 19.79 & .000 & 0.54 \\
\hline Senseless Violence & 1.53 & .57 & 1.83 & .66 & 1.28 & .38 & 1.68 & .74 & 8.43 & .004 & 0.48 & 9.25 & .003 & 0.68 \\
\hline Self-protection Violence & 2.28 & .91 & 2.66 & 1.00 & 1.89 & .81 & 2.44 & 1.01 & 5.68 & .018 & 0.39 & 4.98 & .02 & 0.60 \\
\hline Global Violence & 1.83 & .61 & 2.16 & .74 & 1.52 & .49 & 1.98 & .78 & 8.56 & .004 & 0.48 & 9.26 & .003 & 0.70 \\
\hline
\end{tabular}

Nota. $d=$ Cohen's effect size. Experimental $n=78$, Control $n=65$.

$[\mathrm{F}(1,142)=10.97, p=.001$, $d=0.53]$, being the increase bigger in the EG. Regarding competence, results showed significant differences among groups $[\mathrm{F}(1,142)=13.17, p=.001$, $d=0.52]$, being the increase bigger in the EG. Regarding relatedness, results showed significant differences among groups $[\mathrm{F}(1,142)=19.79$, $p=.001, d=0.54]$, being the increase bigger in the EG. Regarding senseless violence, results showed significant differences among groups $[\mathrm{F}(1,142)=9.25$, $p=.003, d=0.68]$, being the increase bigger in the EG. Regarding self-protection violence, results showed significant differences among groups $[\mathrm{F}(1,142)=4.89$, $p=.02, d=0.60]$, being the in- crease bigger in the EG. Finally, regarding global violence, results showed significant differences among groups $[\mathrm{F}(1,142)=9.26$, $p=.003, d=0.70]$, being the increase bigger in the EG. The MANCOVA did not show significant difference in friendship-approach $[\mathrm{F}(1,142)=3.58, p=.06$, $d=0.33]$, friendship-avoidance $[\mathrm{F}(1,142)=.99, p=.32$, $d=0.04]$, personal responsibility $[\mathrm{F}(1,142)=2.41, p=.12, d=0.37]$ or autonomy $[\mathrm{F}(1,142)=1.19$, $p=.27, d=0.33$ ]. Effect size could be considered moderate in social responsibility (0.53) competence $(0.52)$, relatedness $(0.54)$, senseless violence (0.68), self-protection violence $(0.60)$ and global violence (0.70). 


\section{Discussion}

The main goal of this study was to assess the effects of two different instructional approaches on secondary education students' attitudes on violence, responsibility, friendship goals and basic psychological needs. Results showed that the group that experienced a hybrid SE+TPSR pedagogical model significantly increased more their attitudes towards violence, their social responsibility, their competence and their relatedness. Results from the present study endorse the efficacy of this hybrid approach because they fully confirm hypothesis number 1 and 2 and partially number 4 .

The first hypothesis proposed that the hybrid experimental program (SE+TPSR) will increase more the students' attitudes towards violence and results showed that global violence, senseless violence and self-protection violence increased on both groups, but significantly more on the EG. On the one hand, educational kickboxing has been revealed as a content that does not harm students' attitudes towards violence. Contrary to popular beliefs, it improves them significantly. Its contactless character could be the reason behind the effect. Previous studies have showed that sports such as personal defence, considered non educational by many, also lower students' violence levels (Tejero-González et al., 2011). Therefore, sports con- sidered "violent" can help adolescents' attitudes towards violence when they are modified to fit educational contexts. Moreover, our results also showed that the improvement (decrease) was significantly higher in the group of students that experienced the hybrid SE+TPSR model (the effect size was larger). Therefore, this instructional approach is even better to improve students' attitudes towards violence. Specific features of this hybrid model such as strategies for peaceful resolution of conflicts could have helped reach these results. They are in line with previous studies which also reduced violent attitudes' levels (Tejero-González et al., 2011), improved the class climate and reduced school violence (Carrasco et al., 2015), promoted individuals' socioemotional development and prevented school violence (Garaigordobil \& Martínez-Valderrey, 2014).

The second hypothesis proposed that the experimental program (SE+TPSR) will increase participants responsibility levels, and results have showed that social responsibility increase significantly more in the students that experienced the hybrid model. The fact that one of the (TPSR) was specifically design to develop individuals' personal and social responsibility (Hellison, 2011) could have influenced the increase of one of these values in our students. Previous research works also found an increase in the students' social responsibility 
VIOLENCE, RESPONSIBILITY, FRIENDSHIP AND BASIC PSYCHOLOGICAL NEEDS:

EFFECTS OF A SPORT EDUCATION AND TEACHING FOR PERSONAL

after experiencing intervention programs based on the TPSR model (Caballero, 2015; Escartí et al., 2010; Hastie \& Buchanan, 2010). Individuals' aggressiveness, one of the features of violent conducts, has been negatively linked to responsibility (Gutiérrez, Escartí, \& Pascual, 2011). Our intervention program (SE+TPSR) produced an improvement (increase) in the participants' social responsibility levels and an improvement (decrease) in their attitudes towards violence. This connexion took place only in the EG. Therefore, it could be said that only the hybrid proposal achieved this success and could be widespread if replicated by other researchers.

The third hypothesis proposed that the intervention program based on the pedagogical models will increase students' friendship goals. Results did not support this hypothesis: none of the friendship goal, approach or avoidance, increased after the intervention program. Previous studies reported positive changes in these variables after a SE or TPSR intervention program (Martinek, Schilling, \& Johnson, 2001; Méndez-Giménez, Fernández-Río, \& Méndez Alonso, 2015; Wallhead et al., 2013). However, this was not the case in our study.

The last hypothesis proposed that the students in the EG will increase their basic psychological needs. Results showed that this hypothesis was partially fulfilled be- cause competence and relatedness increased, but autonomy, unexpectedly, did not. Basic elements of SE such as regularly scheduled competitions and the final event where the students tested their learning, and a festive atmosphere on both elements could have helped students increase their autonomy perceptions significantly. Previous studies on SE produced similar results on participants' competence (Cuevas, García-López, \& Contreras, 2015; Hastie, Sinelnikov, \& Guarino, 2009). Similarly, both models include elements that can promote relations among students such as cooperative learning, affiliation or group meetings, which could have reinforced significantly the relations among students. Previous studies have showed that the relationship among students that had experienced SE (García et al., 2012; Perlman \& Goc, 2010) or TPSR (Schilling, 2001; Ward, Parker, Henschel-Pellett, \& Pérez, 2012) had improved.

The presents study also holds some limitations. First, the number of participants could be considered limited and they all belong to the same school grade. Future studies should be conducted on larger populations and from different school grades. Second, students from the EG and the CG were enrolled in two different high schools, but with similar characteristics.

Results from the present study showed the goodness of the hybridization of two pedagogical models, 
SE+TPSR, to improve adolescents' attitudes towars violence, social responsibility, competence and relatedness. Therefore, it is a pedagogi- cal approach worth to be imitated by other teachers for the students' benefits, the whole school community and also society.

\section{References}

Álvarez-García, D., Dobarro, A., Álvarez, L., Núñez, J. C., \& Rodríguez, C. (2014). La violencia escolar en los centros de educación secundaria de Asturias desde la perspectiva del alumnado. Educación XX1, 17(2), 337-360. doi: 10.5944/educxx1.17.2.11494

Álvarez-García, D., Rodríguez, C., González-Castro, P., Núñez, J. C., \& Álvarez, L. (2010). La formación de los futuros docentes frente a la violencia escolar. Revista de Psicodidáctica, 15(1), 35-56. doi: 10.1387/ RevPsicodidact.733

Boulton, M. J. (2013). The effects of victim of bullying reputation on adolescents' choice of friends: mediation by fear of becoming a victim of bullying, moderation by victim status, and implications for befriending interventions. Journal of Experimental Child Psychology, 114, 146-160.

Braithwaite, R., Spray, C. M., \& Warburton, V. E. (2011). Motivational climate interventions in physical education: a meta-analysis. Psychology of Sport and Exercise, 12, 628-638.

Caballero, P. (2015). Diseño, implementación y evaluación de un programa de actividades en la naturaleza para promover la responsabilidad personal y social en alumnos de formación profesional. Cuadernos de
Psicología del Deporte, 15(2), 179194.

Carrasco, C., Alarcón, R., \& Trianes, M. V. (2015). Eficacia de una intervención psicoeducativa basada en el clima social, violencia percibida y sociométricos en alumnado de educación primaria. $R e$ vista de Psicodidáctica, 29(2), 247-262. doi: 10.1387/RevPsicodidact.13206

Cava, M. J., Buelga, S., Musitu, G., \& Murgui, S. (2010). Violencia escolar entre adolescentes y sus implicaciones en el ajuste psicosocial: un estudio longitudinal. Revista de Psicodidáctica, 15(1), 21-34. doi: 10.1387/ RevPsicodidact.732

Cuevas, R., García-López, L. M., \& Contreras, O. (2015). Influencia del modelo de Educación Deportiva en las necesidades psicológicas básicas. Cuadernos de Psicología del Deporte, 15(2), 155-162.

Deci, E. L., \& Ryan, R. M. (1985). Intrinsic motivation and self-determination in human behaviour. New York: Plenum.

Elliot, A. J., Gable, S. L., \& Mapes, R. R. (2006). Approach and avoidance motivation in the social domain. Personality and Social Psychology Bulletin, 32(3), 378-391. doi: $10.1177 / 0146167205282153$ 
VIOLENCE, RESPONSIBILITY, FRIENDSHIP AND BASIC PSYCHOLOGICAL NEEDS:

EFFECTS OF A SPORT EDUCATION AND TEACHING FOR PERSONAL

Escartí, A., Gutiérrez, M., \& Pascual, C. (2011). Propiedades psicométricas de la versión española del cuestionario de responsabilidad personal y social en contextos de educación física. Revista de Psicología del Deporte, 20(1), 119-130.

Escarti, A., Gutiérrez, M., Pascual, C., \& Marín, D. (2010). Applications of Hellison's teaching personal and social responsibility model in physical education to improve self-efficacy for adolescents at risk of droppingout of school. The Spanish Journal of Psychology, 13(2), 667-676.

Fernández-Río, J. (2014). Another step in models-based practice: Hybridizing cooperative learning and teaching for personal and social responsibility. Journal of Physical Education, Recreation and Dance, 85(7), 3-5. doi: 10.1080/07303084.2014.937158

Fernández-Río, J. (2015). Models-based practice reloaded: Connecting cooperative learning and adventure education. Journal of Physical Education, Recreation \& Dance, 86(6), 5-7. doi: 10.1080/07303084.2015.1054197

Garaigordobil, M., \& Martínez-Valderrey, V. (2014). Efecto del Cyberprogram 2.0 sobre la reducción de la victimización y la mejora de la competencia social en la adolescencia. Revista de Psicodidáctica, 19(2), 289-305. doi: 10.1387/RevPsicodidact.10239

García, L. M., Gutiérrez, D., González, S., \& Valero, A. (2012). Cambios de la empatía, la asertividad, y las relaciones sociales por la aplicación del modelo de instrucción Educación Deportiva. Revista de Psicología del Deporte, 21(2), 321-330.

Garn, A. C., \& Wallhead, T. (2014). Social goals and basic psychological needs in high school physical educa- tion. Sport, Exercise, and Performance Psychology, 4(2), 88-99. doi: $10.1037 /$ spy0000029

Gordon, B. (2010). An examination of the responsibility model in a New Zealand secondary school physical education programme. The Journal of Teaching in Physical Education, 29(1), 21-37.

Gordon, B., \& Doyle, S. (2015). Teaching personal and social responsibility and transfer of learning: opportunities and challenges for teachers and coaches. Journal of Teaching in Physical Education, 34, 152-161.

Gutiérrez, M., Escarti, E., \& Pascual, C. (2011). Relaciones entre empatía, conducta prosocial, agresividad, autoeficacia y responsabilidad personal y social de los escolares. Psicothema, 23, 13-19.

Haerens, L., Kirk, D. Cardon, G., \& De Bourdeaudhuij, I. (2011). Toward the development of a pedagogical model for health-based physical education. Quest, 63(3), 321-338. doi: 10.1080/00336297.2011.10483684

Hastie, P. A., \& Buchanan, A. M. (2000). Teaching responsibility through sport education: Prospects of a coalition. Research Quarterly in Exercise and Sport, 71, 25-35. doi: 10.1080/02701367.2000.10608877

Hastie, P. A., \& Casey, A. (2014). Fidelity in models-based practice research in sport pedagogy: A guide for future investigations. Journal of Teaching in Physical Education, 33, 422-431.

Hastie, P. A., Martínez de Ojeda, D., \& Calderón, A. (2011). A review of research on sport education: 2004 to the present. Physical Education and Sport Pedagogy, 16, 103-132. doi: 10.1080/17408989.2010.53520 
Hastie, P. A., Sinelnikov, O. A., \& Guarino, A. J. (2009). The development of skill and tactical competencies during a season of badminton. European Journal of Sport Science, 9(3), 133-140. doi: 10.1080/17461390802542564

Hellison, D. (2011). Teaching personal and social responsibility through physical activity (3rd Ed.). Champaign, IL: Human Kinetics.

IBM Corp. Released (2013). IBM SPSS Statistics for Windows, Version 22.0. Armonk, NY: IBM Corp.

Joyce, B., \& Weil, M. (1985). Modelos de enseñanza. Madrid: Anaya.

King, R. B., \& McInerney, D. M. (2012). Including social goals in achievement motivation research: examples from the Philippines. Online Readings in Psychology and Culture, 5(3). doi: 10.9707/23070919.1104

Li, W., Wright, P. M., Rukavina, P. B., \& Pickering, M. (2008). Measuring students' perceptions of personal and social responsibility and the relationship to intrinsic motivation in urban physical education. Journal of Teaching in Physical Education, 27, 167-178.

Martinek, T., Schilling, T., \& Johnson, D. (2001). Transferring personal and social responsibility of underserved youth to the classroom. The Urban Review, 33(1), 29-45. doi: 10.1023/A:1010332812171

McHugh, E. (1995). Going beyond the physical: Social skills and physical education. Journal of Physical Education, Recreation and Dance, 66(4), 18-21. doi: 10.1080/07303084.1995.10608127

Méndez-Giménez, A., Fernández-Río, J., \& Cecchini-Estrada, J. A. (2013). Papel importante del alumnado, ne- cesidades psicológicas básicas, regulaciones motivacionales y autoconcepto físico en educación física. Cuadernos de Psicología del Deporte, 13(1), 71-82.

Méndez-Giménez, A., Fernández-Río, J., \& Cecchini-Estrada, J. A. (2014). Validación de la versión en española del cuestionario de metas de amistad en educación física. Universitas Psychologica, 13(1), 227-237. doi: 10.11144/Javeriana.UPSY13-1.vvec

Méndez-Giménez, A., Fernández-Río, J., \& Méndez-Alonso, D. (2015). Modelo de educación deportiva versus modelo tradicional: efectos en la motivación y deportividad. $R e$ vista Internacional de Medicina y Ciencias de la Actividad Física y el Deporte, 15(59), 449-466. doi: 10.15366/rimcafd2015.59.004

Menéndez, J. I., \& Fernández-Rio, J. (2014). Innovación en educación física: el kickboxing como contenido educativo. Apunts: Educación Física y Deportes, 11(3), 3342. doi: 10.5672/apunts.2014-0983. es.(2014/3).117.03

Menéndez, J. I., \& Fernández-Río, J. (en prensa). Versión española de la escala de necesidades psicológicas básicas en educación física. Revista Internacional de Medicina y Ciencias de la Actividad Física y el Deporte.

Perlman, D. J., \& Goc, G. (2010). A self-determined perspective of the Sport Education Model. Physical Education and Sport Pedagogy, 15(4), 401-418. doi: $10.1080 / 17408980903535800$

Rovegno, I. (2006). Teaching and learning tactical game play at the elementary school level: the role of situated cognition. In N. Wallian, M. P. Poggi, y M. Musard (Eds), Co- 


\section{VIOLENCE, RESPONSIBILITY, FRIENDSHIP AND BASIC PSYCHOLOGICAL NEEDS: EFFECTS OF A SPORT EDUCATION AND TEACHING FOR PERSONAL

construire des savoirs: les metiers de l'intervention dans les APSP (pp. 115-126). Besançon: Presses universitaries de Franche-Comte.

Schilling, T. (2001). An investigation of commitment among participants in an extended day physical activity program. Research Quarterly for Exercise and Sport, 72(4), 355-365. doi: 10.1080/02701367.2001.10608972

Siedentop, D., Hastie, P. A., \& van Der Mars, H. (2011). Complete guide to Sport Education (2. ${ }^{\mathrm{a}}$ Ed.). Champaign, IL: Human Kinetics.

Standage, M., Duda, J. L., \& Ntoumanis, N. (2005). A test of self-determination theory in school physical education. British Journal of Physical Education, 74, 411-433. doi: 10.1348/000709904X22359

Tejero-González, C. M., BalsalobreFernández, C., \& Ibáñez-Cano, A. (2011). La defensa personal como intervención educativa en la modificación de actitudes violentas. $R e$ vista Internacional de Medicina y Ciencias de la Actividad Física y del Deporte, 11(43), 513-530.

Turnnidge, J., Côté, J., \& Hancock, D. J. (2014). Positive youth development from sport to life: Explicit or implicit transfer? Quest, 66(2), 203-217. doi: 10.1080/00336297.2013.867275

Vlachopoulos, S. P., Katartzi, E. S., \& Kontou, M. G. (2011). The basic psychological needs in physical education scale. Journal of Teaching in Physical Education, 30, 263-280.

Wallhead, T. L., Garn, A. C., \& Vidoni, C. (2013). Sport education and social goals in physical education: Relationships with enjoyment, relatedness and leisure-time physical activity. Physical Education and Sport Pedagogy, 18(4), 427-441. doi: 10.1080/17408989.2012.690377

Wallhead, T. L., Garn, A. C., \& Vidoni, C. (2014). Effect of a sport education program on motivation for physical education and leisure-time physical activity. Research Quarterly for Exercise and Sport, 85, 478-487. doi: 10.1080/02701367.2014.961051

Ward, S., Parker, M., Henschel-Pellett, H., \& Perez, M. (2012). Forecasting the storm: Student perspectives throughout a teaching personal and social responsibility (TPSR)based positive youth development program. Ágora para la Educación Física y el Deporte, 14(2), 230-247. 
José Ignacio Menéndez Santurio, Master's degree in Socioeducative Intervention and Research and doctoral candidate at the University of Oviedo. Research lines: martial arts, combat sports and pedagogical models, specially Sport Education and Teaching for Personal and Social Responsibility.

Javier Fernández-Río, Associate Professor in the Area of Body Language Didactics at the University of Oviedo. Research lines: pedagogical models and motivation. 